\title{
Enzymes of Clostridium welchii Type A and Clostridium histolyticum that Disintegrate Decalcified Human Tooth Dentine
}

\author{
By D. G. EVANS and A. S. PROPHET* \\ Department of Bacteriology and Turner Dental School, University of Manchester
}

SUMMARY: Enzymes elaborated by Clostridium histolyticum and by $\mathrm{Cl}$. welchii type A that disintegrated the organic component of human tooth dentine were compared with those attacking muscle collagen.

The potency of specific antisera to neutralize the enzymes disintegrating the organic component of dentine was determined by using as indicator finely divided decalcified dentine suspended in an agar gel.

By comparing the potency values of the sera with those obtained when muscle collagen preparations were used as indicators, it was evident that the organic component of dentine was attacked by the collagenases of $C l$. welchii type A ( $\kappa$ antigen) and $\mathrm{Cl}$. histolyticum ( $\beta$ antigen) and probably by the $\gamma$ antigen of $\mathrm{Cl}$. histolyticum. The $\lambda$ antigen of $\mathrm{Cl}$. welchii type $\mathrm{B}$ had no action on decalcified dentine.

Oakley, Warrack \& van Heyningen (1946) showed that the collagenase ( $\kappa$ antigen) of Clostridium welchii type $\mathbf{A}$, which attacks muscle collagen, was antigenically distinct from the other known antigens produced by this organism and devised methods to determine the anticollagenase potency of specific antisera, using collagen preparations as indicators. Evans (1947) investigated the production, by certain species of Clostridium, of enzymes disintegrating finely divided hide-powder, which, although a convenient and rich source of collagen, was not regarded as a pure substrate; and its disintegration not considered a specific indication of collagenase. Of the organisms examined by this method, $\mathrm{Cl}$. histolyticum and $\mathrm{Cl}$. welchii type $\mathrm{A}$ were found to be the most active producers of enzyme. It was later reported by Oakley, Warrack \& Warren (1948) that hide-powder was not a reliable indicator for collagenase, for this substrate was also attacked by a second enzyme, the $C l$. welchii $\lambda$ antigen which had no action on collagen. They suggested that during the preparation of hide-powder, the collagen was altered in some way so as to make it susceptible to attack by the $\lambda$ antigen. They showed that $\lambda$ antigen was produced by $C l$. welchii types $\mathrm{B}, \mathrm{E}$ and $\mathrm{D}$, whereas collagenase was produced by types $\mathbf{A}, \mathrm{C}, \mathrm{D}$ and E. Oakley \& Warrack (1950) also demonstrated that $\mathrm{Cl}$. histolyticum produced two enzymes, each of which was antigenic, one a collagenase ( $\beta$ antigen) which attacked collagen and hide-powder, and the other ( $\gamma$ antigen) which attacked hide-powder but not collagen. Each of these enzymes was antigenically distinct from the lethal toxin of $\mathrm{Cl}$. histolyticum.

Recently we showed (Evans \& Prophet, 1950) that certain species of Clostridium and Bacillus formed enzymes which disintegrated the collagen-like matrix of human tooth dentine. Among the Clostridium species, Cl. histo-

* Nuffield Research Fellow. 
lyticum and $\mathrm{Cl}$. welchii type $\mathrm{A}$ were the most active, and the question was considered as to whether these enzymes were related to those attacking the collagen of muscle. The problem was most conveniently investigated by determining the potency of specific antisera to neutralize the enzymes responsible for disintegration of dentine collagen and comparing the results with those obtained when muscle collagen was used as indicator.

\section{EXPERIMENTAL AND RESULTS}

\section{Preparation of dentine substrate}

The dentine substrate was prepared by the method of Evans \& Prophet (1950). Human tooth dentine was ground in a low-temperature ball-mill and the finely divided powdered dentine decalcified by $0.2 \mathrm{~N}-\mathrm{HCl}$. The decalcified dentine powder, when washed free from acid and dried, served as the substrate. For testing the activity of enzymes, the powder was suspended in melted $4 \%$ agar of neutral $\mathrm{pH}$ and pour-plates made in Petri dishes in which the particles of decalcified dentine were densely and uniformly distributed in a concentration of $0.1 \mathrm{~g} . / 100 \mathrm{ml}$. of agar.

\section{Titration of enzymes}

Dried ammonium sulphate precipitates from filtrates of broth cultures of $\mathrm{Cl}$. relchii type $\mathrm{A}$ and $\mathrm{Cl}$. histolyticum were titrated by a cup-plate method. Cups of $6 \mathrm{~mm}$. diameter were cut with a cork-borer in decalcified dentine agar plates and approximately $0.1 \mathrm{ml}$. of increasing dilutions of a saline solution of the toxic precipitate were pipetted into each cup. The plates were incubated at $37^{\circ}$ and after $24 \mathrm{hr}$. active dilutions produced around the cup a clear concentric zone in which the dentine particles were completely dissolved; the zone increased in size on incubating a further $24 \mathrm{hr}$., when the final readings were made. The average minimal effective dose (m.e.d.) of enzyme preparation chosen for the tests, was $0.008 \mathrm{mg} . / \mathrm{ml}$. for $\mathrm{Cl}$. histolyticum and $0.15 \mathrm{mg} . / \mathrm{ml}$. for $\mathrm{Cl}$. welchii type A. With each enzyme preparation one minimal effective dose (1 m.e.d.) gave a zone of $10 \mathrm{~mm}$. diameter, while dilutions containing 10 m.e.d. or more gave $\mathbf{3 0} \mathrm{mm}$. zones.

\section{Neutralization of enzymes by antisera}

The cup-plate method was used to titrate the neutralizing potency of specific antisera against enzyme present in the enzyme preparations. The antisera had been prepared in horses and tested by $\mathrm{Dr}$ C. L. Oakley for neutralization of enzymes attacking collagen. Each antiserum was titrated by making saline dilutions and to each dilution an equal volume of a solution of the homologous enzyme preparation was added. Each serum dilution in the series differed from the next by $10 \%$ or less. After standing at room temperature for 30 min., $0.1 \mathrm{ml}$. of each mixture was pipetted into the cups and the plates incubated at $37^{\circ}$ for $48 \mathrm{hr}$. With most of the titrations each cup contained 100 m.e.d. of enzyme. With low titre sera, however, weaker concentrations of enzyme were used to obtain an end-point in the titration.

Table 1 gives the results of the tests with eight $C l$. welchii antisera using GMIV 3 
Table 1. Neutralization by Clostridium welchii antisera of enzymes disintegrating (a) decalcified dentine and $(b)$ collagen

$\begin{array}{lcc}\text { Antiserum } & \begin{array}{c}\text { Neutralizing values using as indicator } \\ \text { Decalcified } \\ \text { dentine }\end{array} & \begin{array}{c}\text { Collagen } \\ \text { (anti-k) }\end{array} \\ \text { RX 1308 (Standard) } & 470 & 470 \\ \text { RX 5167 } & 5600 & 4800 \\ \text { R 8480 } & 8700 & 7100 \\ \text { RX 5457/36 } & 85 & 80 \\ \text { EX 1055 } & 5 & 5 \\ \text { R 5434 } & 2900 & 2400 \\ \text { R 6423 } & 60 & 60 \\ & <1 & c .1\end{array}$

serum EX 1308 as a standard, in terms of which the relative anti-enzymic activity of the other sera is expressed. The table also includes, for comparison, the anticollagenase values. It was evident that the neutralizing value of each Cl. welchii antiserum when tested with decalcified dentine as indicator, was of the same order as the anticollagenase value. This relationship suggests that the active antibody in both tests was in fact an anticollagenase, and that collagenase was responsible for the disintegration of decalcified dentine. It does not, however, follow from these findings that the organic component of dentine was identical with the collagen of muscle.

Table 2. Neutralization by Clostridium histolyticum antisera of enzymes disintegrating (a) decalcified dentine, $(b)$ collagen and $(c)$ hide-powder

Neutralizing values using as indicator

$\begin{array}{lccc}\text { Antisera } & \begin{array}{c}\text { Decalcified } \\ \text { dentine }\end{array} & \text { Collagen } & \text { Hide-powder } \\ \text { RR 2001 (Standard) } & 100 & 100 & 100 \\ \text { RR 2008 } & 400 & 370 & \mathbf{3 5 0} \\ \text { H 1982A } & 250 & 260 & 230 \\ \text { H 1982B } & 165 & 180 & 175 \\ \text { RR 2005 } & 185 & 330 & 165 \\ \text { RR 2035 } & 165 & 230 & 190\end{array}$

Table 2 gives the results of the titrations of six $\mathrm{Cl}$. histolyticum antisera and the corresponding anticollagenase values. In this case serum RR 2001 was used as standard. There was not the same close relationship between the two sets of values in these tests as there was with the $\mathrm{Cl}$. welchii antisera. The values for four sera agree very well and were presumably determined against collagenase in both cases. The values for each of the sera RR 2005 and RR 2035 however did not agree, suggesting that $\mathrm{Cl}$. histolyticum produces, in addition to collagenase, another enzyme capable of attacking decalcified dentine. Oakley \& Warrack (1950) in testing the same six Cl. histolyticum antisera with dyed hidepowder (azocoll) as indicator found that these two sera had potencies with that indicator which were different from their anticollagenase potencies. A typical set of their results with hide-powder is given in Table 2 for comparison. They 
contended that these discrepant results were due to a second enzyme, which they named $\gamma$ antigen, which attacked hide-powder but not collagen. It is highly probable that the discrepant results in titrating sera RR 2005 and RR 2035 with decalcified dentine as indicator were also due to this second enzyme $\gamma$.

\section{Neutralization tests with dentine decalcified by mild treatment}

The results with $\mathrm{Cl}$. histolyticum antisera suggested that decalcified dentine was disintegrated not only by collagenase but also by an enzyme which attacked degraded collagen in the form of hide-powder. It was possible that the organic component of dentine was degraded during decalcification, making it susceptible to attack by enzymes which attacked degraded collagen. We could not investigate this problem by using as substrate the organic component as it occurred in its natural form, for it was not susceptible to enzyme attack until it was separated from the inorganic-organic complex by decalcification (Evans \& Prophet, 1950). It was possible, however, to decalcify dentine by a mild acid treatment unlikely to cause degradation of the organic component and to use the preparation for titrating the $\mathrm{Cl}$. histolyticum sera.

Table 3. Neutralization by Clostridium histolyticum antisera of enzymes disintegrating (a) dentine decalcified at $\mathrm{pH} 6.0$ and $(b)$ collagen

Antisera
RR 2001 (Standard)
RR 2008
H 1982 A
H 1982 B
RR 2005
RR 2035

$\begin{array}{cc}\begin{array}{c}\text { Dentine decalcified } \\ \text { at pH 6.0 }\end{array} & \begin{array}{c}\text { Collagen } \\ \text { (anti- } \beta \text { ) }\end{array} \\ 100 & 100 \\ 395 & 370 \\ 280 & 260 \\ 180 & 180 \\ 180 & 330 \\ 165 & 230\end{array}$

Pour-plates of finely divided dentine powder in $4 \%$ agar were prepared, in which the dentine particles were uniformly distributed in a concentration of $0.4 \mathrm{~g} . / 100 \mathrm{ml}$. of agar. From these plates $6 \mathrm{~mm}$. agar disks were cut and decalcified by placing in excess buffer solution (Evans \& Prophet, 1950). Disks treated with McIlvaine phosphate-citric acid buffer at pH 6.0 (cf. Clark, 1928) were employed as indicator in the titration of the $\mathrm{Cl}$. histolyticum sera. Serum dilutions were mixed with solutions containing 100 m.e.d./ml. of enzyme. Into each mixture a decalcified dentine agar disk was placed and the mixtures incubated at $37^{\circ}$. After $24 \mathrm{hr}$. disks from tubes where enzyme had not been entirely neutralized were completely clear, whereas those from tubes where neutralization had occurred contained visible particles of decalcified dentine. The results of these titrations are given in Table 3 together with the values obtained when collagen was used as indicator. Again the values for sera RR 2005 and RR 2035 did not agree with those for anticollagenase activity, suggesting that dentine decalcified by mild treatment is susceptible to attack by both collagenase of $\mathrm{Cl}$. histolyticum and another enzyme, probably $\gamma$, and that 
the susceptibility to the second enzyme is not due to the degradation of the organic component during decalcification.

Although decalcified dentine was apparently susceptible to attack by the $\gamma$ antigen of $\mathrm{Cl}$. histolyticum, it was not however attacked by the $\lambda$ antigen of $C l$. relchii type B. A preparation of $\lambda$ antigen had no disintegrating action on decalcified dentine in a concentration 100 times the minimal dose active with hide-powder.

\section{CONCLUSIONS}

It was evident from these results that the organic component of human tooth dentine was attacked by the collagenases of $C l$. welchii type $\mathbf{A}$ ( $\kappa$ antigen) and Cl. histolyticum ( $\beta$ antigen) and probably by the $\gamma$ antigen of $\mathrm{Cl}$. histolyticum but not by the $\lambda$ antigen of $C l$. welchii type $B$.

We should like to express our thanks to Dr C. L. Oakley for helpful advice and for supplies of antisera and $\lambda$ antigen of $\mathrm{Cl}$. welchii type B.

\section{REFERENCES}

CLARK, W. M. (1928). The determination of hydrogen ions, 3rd ed. London: Baillière, Tindall and Cox.

Evans, D. G. (1947). The production by certain species of Clostridium of enzymes disintegrating hide-powder. J. gen. Microbiol. $1,378$.

Evans, D. G. \& Prophet, A. S. (1950). The disintegration of human dentine by bacterial enzymes. Lancet, $\mathrm{i}, 290$.

OAKLey, C. L. \& Warrack, G. H. (1950). The Alpha, Beta and Gamma Antigens of Clostridium histolyticum (Weinberg \& Séguin, 1916). J. gen. Microbiol. 4, 365.

Oakiey, C. L., Warrack, G. H. \& Heyningen, W. E. van (1946). The collagenase ( $\kappa$ toxin) of Cl. welchii type A. J. Path. Bact. 58, 229.

OAKreY, C. L., Warrack, G. H. \& Warren, M. E. (1948). The kappa and lambda antigens of Cl. welchii. J. Path. Bact. 60, 495. 